\title{
Pengembangan Media Pembelajaran Macromedia Flash berbasis Discovery Learning pada Materi Larutan Penyangga Kelas XI MIA 1 SMAN 9 Makassar
}

\author{
Development of Macromedia Flash Learning Media based on Discovery \\ Learning on Buffer Solution Subject Matter Class XI MIA 1 SMAN 9 \\ Makassar
}

\author{
${ }^{1)}$ Haryani, ${ }^{2)}$ Muh. Yunus, ${ }^{3)}$ Muhammad Anwar \\ 123) Jurusan Kimia Fakultas Matematika dan Ilmu Pengetahuan Alam \\ Universitas Negeri Makassar, Jl. Dg Tata Raya Makassar, Makassar 90224 \\ Email:yanikitty7@gmail.com
}

\begin{abstract}
ABSTRAK
Penelitian ini adalah penelitian research and development (R\&D) yang bertujuan untuk memperoleh media pembelajaran macromedia flash berbasis discovery learning pada materi larutan penyangga dan yang valid, praktis dan efektif. Tahapan pengembangan mengacu pada model ADDIE meliputi tahapan analysis, design, develop, implementation, dan evaluation. Pengambilan data dilakukan dengan menggunakan lembar validasi, angket, postest dan dokumentasi yang selanjutnya dianalisis dengan metode deskriptif kuantitatif. Hasil validasi produk pengembangan media pembelajaran macromedia flash berbasis discovery learning dari ahli materi dan ahli media masing-masing termasuk kategori valid dan sangat valid. Kepraktisan media pembelajaran ditinjau dari angket tanggapan peserta didik, angket tanggapan guru dan lembar observasi keterlaksanaan perangkat masing-masing termasuk kategori sangat tinggi, tinggi dan sangat tinggi. Keefektifan media pembelajaran ditinjau dari motivasi belajar peserta didik termasuk kategori tinggi dan perbandingan persentase ketuntasan hasil post-test kelas uji coba dengan kelas pembanding berturut-turut yaitu $62,5 \%$ dan $59,3 \%$. Berdasarkan hasil analisis data dapat disimpulkan bahwa media pembelajaran yang diperoleh valid, praktis dan efektif untuk diterapkan dalam pembelajaran kimia pada materi larutan penyangga.

Kata Kunci: Macromedia flash, model pembelajaran discovery learning
\end{abstract}

\begin{abstract}
This research is a research and development $(\mathrm{R} \& \mathrm{D})$ that aimed to product learning media macromedia flash based discovery learning on buffer solution subject matter and determine the valid, practic and effective. The development stages refers to ADDIE models, namely analysis, design, develop, implementation, and evaluation. Data collection was done with using validation sheet, questionnaire, post-test and documentation which are analyzed with quantitative descriptive analysis method. The validation result of development learning media products macromedia flash based discovery learning for its learning content
\end{abstract}


standards, learning, language, software engineering and visual display and audio respectively obtained 3,$9 ; 3,6 ; 5 ; 4,1$ dan 4.6 . Practicality of learning media in terms of student responses questionnaire, teacher responses and observation sheet of device implementation respectively obtained $82.21 \%$, $78.5 \%$ and 89.55 . The effectiveness of learning media in terms of the student motivation got percentage $70.49 \%$ and a comparison of the percentage of completeness posttest results of trials with control class, respectively obtained $62.5 \%$ and $59.3 \%$. Finally, it can be concluded that the learning macromedia flash based discovery learning is valid, practical and effective be applied in learning chemistry on buffer solution subject matter

Keywords: Learning media, macromedia flash, discovery learning model

\section{PENDAHULUAN}

Pendidikan merupakan salah satu faktor utama dalam pembentukan pribadi manusia. Pendidikan memiliki peran yang sangat dominan dalam membentuk baik atau buruknya pribadi manusia berdasarkan ukuran normatifnya. Pemerintah menyadari akan hal tersebut, berbagai upaya dilakukan pemerintah dalam meningkatkan kualitas pendidikan. Salah satunya yaitu dengan peralihan dari Kurikulum Tingkat Satuan Pendidikan (KTSP) ke Kurikulum 2013 (K13).

Kurikulum 2013 menuntut pembelajaran yang berpusat pada peserta didik (student center). Salah satu model pembelajaran yang direkomendasikan oleh kurikulum 2013 adalah model pembelajaran discovery learning. Bruner dalam Dahar (1996) menganggap bahwa belajar dengan model penemuan sesuai dengan pencarian pengetahuan secara aktif oleh manusia menghasilkan pengetahuan yang benar-benar bermakna bagi peserta didik.

Dalam mengaplikasikan model pembelajaran discovery learning guru berperan sebagai pembimbing dengan memberikan kesempatan kepada peserta didik untuk belajar secara aktif, sebagaimana mestinya guru harus dapat membimbing dan mengarahkan kegiatan belajar peserta didik sesuai dengan tujuan pembelajaran. Di dalam discovery learning bahan ajar tidak disajikan dalam bentuk akhir, peserta didik dituntut untuk melakukan berbagai kegiatan menghimpun sejumlah informasi, membandingkan, mengkategorikan, menganalisis, mengintegrasikan, mengorganisasikan bahan serta membuat kesimpulan sendiri (Jamil, 2013).

\begin{tabular}{lrr}
\multicolumn{2}{c}{ Model } & \multicolumn{2}{r}{ pembelajaran } \\
discovery & learning & dalam \\
penerapannya & pada & proses
\end{tabular}
pembelajaran tidak maksimal. Guru belum dalam membimbing peserta didik melakukan proses pembelajaran secara discovery di dalam kelas. Berdasarkan hasil wawancara dengan guru kimia SMAN 9 Makassar, mereka belum pernah menggunakan model pembelajaran discovery learning hal ini dikarenakan guru lebih terbiasa dengan model ceramah. Apalagi selama ini belum ada sesuatu yang bisa memudahkan guru dalam menerapkan 
model pembelajaran discovery learning.

Ilmu kimia sebagai ilmu pengetahuan alam yang mempelajari tentang struktur, susunan, sifat dan perubahan materi serta energi yang menyertainya sehingga menyebabkan ilmu ini dianggap rumit oleh peserta didik (Tsaparlis,2003). Salah satu materi pokok yang membutuhkan penalaran tinggi dalam pelajaran kimia adalah materi larutan penyangga yang berpotensi untuk menyebabkan rendahnya pemahaman konsep pada peserta didik (Ma'rifah, 2012).

Media pembelajaran adalah teknologi pembawa pesan yang dapat dimanfaatkan keperluan pembelajaran. Maka media pembelajaran adalah suatu alat atau saluran yang digunakan untuk menyampaikan materi pelajaran dalam proses pmebelajaran (Arsyad, 2011).

Media pembelajaran memiliki fungsi utama media pembelajaran adalah sebagai alat bantu dalam mengajar yang dapat memotivasi peserta didik dan dapat menarik perhatian peserta didik. Salah satu media pembelajaran yang dapat digunakan adalah media pembelajaran macromedia flash berbasis discovery learning. Selain dapat memotivasi peserta didik juga dapat memudahkan peserta didik untuk belajar dengan model pembelajaran discovery learning di kelas.

Pengembangan media pembelajaran macromedia flash yang berbasis discovery learning dapat mendukung penerapan model pembelajaran discovery learning. penelitian pengembangan adalah suatu proses atau langkah-langkah untuk mengembangkan suatu produk baru atau menyempurnakan produk yang telah ada, yang dapat dipertanggungjawabkan (Mulyatiningsih, 2008).

Berdasarkan uraian sebelumnya, peneliti bermaksud untuk mengadakan penelitian dengan judul "Pengembangan Media Pembelajaran Macromedia Flash Berbasis Discovery Learning pada Materi Larutan Penyangga di Kelas XI MIA SMAN 9 Makassar".

\section{METODE PENELITIAN}

Penelitian ini merupakan penelitian pengembangan (Research and Development) yang menghasilkan produk media pembelajaran macromedia flash berbasis discovery learning untuk pembelajaran materi larutan penyangga. Penelitian ini merujuk pada model pengembangan ADDIE (Analysis, Design, Develop, Implementation, Evaluation).

Tahap analisis dilakukan analisis kebutuhan peserta didik untuk melihat media yang benar-benar dibutuhkan peserta didik, analisis kurikulum berupa KI, KD, metode serta model pembelajaran yang digunakan.

Tahap desain melakukan
perancangan media meliputi
pembuatan desain media secara
keseluruhan meliputi, materi, soal
evaluasi, penentuan background,
pembuatan gambar dan animasi.
Penyusunan instrumen penilaian
produk berupa instrumen kevalidan,
kepraktisan dan keefektifan.
Tahap pengembangan adalah
tahap pembuatan produk berdasarkan
desain. Produk yang dihasilkan


Pengembangan Media Pembelajaran Macromedia Flash berbasis Discovery Learning pada Materi Larutan Penyangga Kelas XI MIA I SMAN 9 Makassar

divalidasi oleh ahli materi dan media melaui angket validasi. Para ahli memberikan masukan sebagai dasar untuk melakukan revisi terhadap produk yang dikembangkan hingga validator menyatakan layak diujicobakan.

Tahap implementasi yaitu melakukan ujivoba terbatas pada kelas XI MIA 1 SMAN 9 Makassar. Pada tahap ini dibagikan lembar observasi untuk melihat keterlaksanaan pembelajaran, angket untuk mengetahui penilaian peserta didik dan guru terhadap media yang dikembangkan.

Tahap evaluasi meliputi pengukuran ketercapaian produk dengan menghitung kevalidan, kepraktisan dan keefektifan media pembelajaran.

Data yang diperoleh dari penelitian ini dianalisis untuk mengetahui tingkat kevalidan, kepraktisan dan keefektifan. Untuk kevalidan media dari ahli materi ataupun media dengan rumus:

$$
\text { Rata-rata penilaian }=\frac{\text { jumlah skor penilaian }}{\text { jumlah penilai }} \times 100
$$

Untuk kepraktisan media dari lembar observasi keterlaksanaan pembelajaran dengan rumus:

$$
\text { Persentase keterlaksanaan }=\frac{\sum \mathrm{x}}{\mathrm{N}} \mathrm{X} 100
$$

dan respon peserta didik maupun guru dengan rumus:

$$
\% \text { Rata-rata respon }=\frac{\text { Rata }- \text { rata respon }}{4} \times 100 \%
$$

Untuk keefektifan media dari hasil belajar dengan rumus:

$$
\begin{gathered}
\text { Nilai }=\frac{\text { skor yang diperoleh peserta didik }}{\text { skor maksimum }} \times 100 \\
\% \text { ketuntasan kelas }=\frac{\sum \text { peserta didik tuntas }}{\sum \text { semua peserta didik }} \times 100
\end{gathered}
$$

dan motivasi belajar dengan rumus:

$$
\text { Angka persentase }=\frac{\text { skor yang diperoleh }}{\text { skor ideal }} \times 100 \%
$$

\section{HASIL DAN PEMBAHASAN}

\section{A. Hasil Penelitian}

Hasil pada tahap analisis diperoleh bahwa SMAN 9 Makassar telah menerapkan kurikulum 2013 namun pada kenyataanya di kelas guru masih menggunakan metode ceramah sehingga peserta didik menjadi pasif dalam proses pembelajaran. Terkait isi materi larutan penyangga yang telah dianalisis, maka model pembelajaran yang dianggap tepat adalah model pembelajaran discovery learning dan untuk memudahkan penerapan model pembelajaran discovery learning digunakan media pembelajaran macromedia flash berbasis discovery learning.

Tahap desain dilakukan dengan melakukan perancangan media pembelajaran berdasarkan pendekatan scientific yaitu berbasis discovery learning. Tahap desan secara keseluruhan meliputi pembuatan desain media pembelajaran secara keseluruhan (storyboard), penyusunan materi, soal evaluasi, penentuan background, pembuatan gambar dan animasi.

Tahap pengembangan meliputi pembuatan dan validasi produk. Pembuatan produk 
Pengembangan Media Pembelajaran Macromedia Flash berbasis Discovery Learning pada Materi Larutan Penyangga Kelas XI MIA I SMAN 9 Makassar

menggunakan aplikasi Macromedia flash dan Adobe Flash CS6. Produk yang diperoleh divalidasi oleh ahli materi dan ahli media. Penilaian ahli materi meliputi aspek standar isi materi larutan penyangga dan pembelajaran. Penilaian ahli media meliputi aspek kebahasaan, rekayasa perangkat lunak dan tampilan audio dan visual. Para ahli juga memberikan masukan yang selanjutnya dilakukan tindak lanjut berupa revisi pada media yang telah dibuat. Hasil penilaian kevalidan media terlihat pada Tabel 1.

Tabel 1. Hasil Penilaian Kevalidan Media

\begin{tabular}{ccc}
\hline Penilaian & $\begin{array}{c}\text { Rata- } \\
\text { rata }\end{array}$ & Kategori \\
\hline Ahli materi & 3,75 & Valid \\
\hline Ahli media & 4,56 & $\begin{array}{c}\text { Sangat } \\
\text { Valid }\end{array}$ \\
\hline
\end{tabular}

Media yang telah dinyatakan valid dapat digunakan pada tahap implementasi yaitu uji coba terbatas. Lembar observasi keterlaksanaan pembelajaran berdasarkan sintaks discovery learning meliputi penilaian tahap pendahuluan, fase stimulation, fase problem statement, fase data collecting, fase data processing, fase verification, fase generalization dan tahap penutup.

Angket tanggapan peserta didik meliputi aspek tampilan, pembelajaran dan isi/materi. Angket tanggapan guru mencakup aspek kesesuaian materi, penyajian materi, rekayasa media dan komunikasi visual. Hasil penilaian kepraktisan media terlihat pada Tabel 2.
Tabel 2. Hasil Penilaian Kepraktisan Media

\begin{tabular}{lll}
\hline Penilaian & $\begin{array}{l}\text { Rata- } \\
\text { rata }\end{array}$ & Kategori \\
\hline $\begin{array}{l}\text { Observasi } \\
\begin{array}{l}\text { Keterlaksanaan } \\
\text { Pembelajaran }\end{array}\end{array}$ & $94,6 \%$ & $\begin{array}{l}\text { Sangat } \\
\text { Tinggi }\end{array}$ \\
\hline $\begin{array}{l}\text { Tanggapan } \\
\text { peserta didik }\end{array}$ & $82,2 \%$ & $\begin{array}{l}\text { Sangat } \\
\text { Tinggi }\end{array}$ \\
\hline Tanggapan guru & $75 \%$ & $\begin{array}{l}\text { Sangat } \\
\text { Tinggi }\end{array}$ \\
\hline
\end{tabular}

Hasil penilaian keefektifan media terlihat pada Tabel 3.

Tabel 3. Hasil Penilaian Keefektifan Media

\begin{tabular}{|c|c|c|}
\hline Penilaian & $\begin{array}{l}\text { Rata- } \\
\text { rata }\end{array}$ & Kategori \\
\hline $\begin{array}{l}\text { Tes Hasil } \\
\text { Belajar } \\
\text { Kelas Uji } \\
\text { Coba }\end{array}$ & $62,5 \%$ & $\begin{array}{l}\text { Kurang dari } \\
\% \\
\text { ketuntasan } \\
\text { kelas } \\
\text { minimum }\end{array}$ \\
\hline $\begin{array}{l}\text { Tes Hasil } \\
\text { Belajar } \\
\text { Kelas } \\
\text { Pembanding }\end{array}$ & $59,3 \%$ & $\begin{array}{l}\text { Kurang dari } \\
\% \\
\text { ketuntasan } \\
\text { kelas } \\
\text { minimum }\end{array}$ \\
\hline $\begin{array}{l}\text { Motivasi } \\
\text { Belajar }\end{array}$ & $81 \%$ & $\begin{array}{l}\text { Sangat } \\
\text { Tinggi }\end{array}$ \\
\hline
\end{tabular}

\section{B. Pembahasan}

Pengembangan Media Pembelajaran Macromedia Flash berbasis Discovery Learning ini, diadaptasi dari rangkuman aktivitas model ADDIE. Model ADDIE terdiri dari lima tahap yaitu 1) Analysis, 2) Design, 3) Development, 4) Implementation, dan 5) Evaluation. Penelitian ini dibatasi hanya sampai 
Pengembangan Media Pembelajaran Macromedia Flash berbasis Discovery Learning pada Materi Larutan Penyangga Kelas XI MIA I SMAN 9 Makassar

tahap implementasi untuk kelas terbatas saja dan tahap evaluasi hanya sampai pada analisis kepraktisan dan keefektifan media pembelajaran pada uji kelas kecil (terbatas).

Penilaian ahli materi dari beberapa aspek dengan kategori valid telah sesuai dengan apa yang dinyatakan oleh Sumiharsono (2017) bahwa isi media pembelajaran harus relevan dengan kompetensi yang ingin dicapai, media pembelajaran mengandung materi yang lengkap, media pembelajaran merupakan pembawa informasi yang mampu menyampaikan isi pembelajaran.

Hasil penilaian ahli media dari beberapa aspek dengan kategori sangat valid juga telah sesuai dengan apa yang dinyatakan oleh Arsyad (2005) bahwa media mampu membuat konkrit konsep-konsep yang abstrak, dapat membuat proses pembelajaran lebih menarik, membuat pembelajaran lebih efisien dengan media yang mudah untuk dioperasikan.

Dari keseluruhan hasil uji kevalidan terhadap media yang dikembangkan, dapat disimpulkan bahwa media pembelajaran macromedia flash berbasis discovery learning untuk materi larutan penyangga valid digunakan dalam pembelajaran.

Tingginya persentase hasil keterlaksanaan pembelajaran yang diperoleh mendandakan bahwa media macromedia flash berbasis discovery learning mudah untuk diterapkan dalam proses pembelajaran. Aspek penilaian tanggapan peserta didik dan guru pada dasarnya sama dengan aspek penilaian kevalidan media. Oleh karenanya dari segi pandangan peserta didik dan guru, media yang dikembangkan juga telah sesuai apa yang dinyatakan oleh Sumiharsosno (2017) bagaimana karakteristik sebuah media pembelajaran.

Dari keseluruhan hasil uji kepraktisan terhadap media yang dikembangkan, dapat disimpulkan bahwa media pembelajaran macromedia flash berbasis discovery learning untuk materi larutan penyangga praktis digunakan dalam pembelajaran.

Hasil belajar peserta didik masih kurang dari \% ketuntasan minimum sehingga dari segi ketuntasan belajar media pembelajaran belum dikatakan efektif. Hal ini disebabkan karena peserta didik belum terbiasa dengan model discovery learning sehingga dapat dikatakan mereka masih belajar untuk aktif dan mencari sendiri konsep materi berdasarkan indikator per pertemuan. Dilihat dari ketuntasan indikator, rata-rata indikator tuntas namun ada dua indikator yang tidak tuntas yaitu perhitungan $\mathrm{pH}$ dan prinsip kerja larutan penyangga. Sehingga diharapkan penelitian pengembangan selanjutnya menambahkan latihan soal agar hasil belajar peserta didik dapat meningkat. Motivasi peserta didik dalam kategori sangat tinggi sehingga jika dilihat dari motivasi peserta didik, dapat dikatakan efektif.

yang diperoleh sesuai dengan penelitian yang dilakukan oleh Subhan (2018) bahwa media pembelajaran memiliki pengaruh yang signifikan terhadap hasil belajar dan motivasi belajar kimia peserta didik. 
Dari keseluruhan hasil uji keefektifan terhadap media yang dikembangkan, dapat disimpulkan bahwa media pembelajaran macromedia flash berbasis discovery learning untuk materi larutan efektif digunakan dalam pembelajaran.

\section{KESIMPULAN DAN SARAN}

\section{A. Kesimpulan}

Berdasarkan hasil penelitian maka dapat disimpulkan bahwa media pembelajaran macromedia flash berbasis discovery learning untuk materi larutan penyangga dikembangkan dengan menggunakan model pengembangan ADDIE yang terdiri atas tahap analisis, desain pengembangan, implementasi dan evaluasi. Media pembelajaran macromedia flash berbasis discovery learning dinyatakan valid dengan kategori sangat valid setelah divalidasi oleh para ahli, dinyatakan praktis dengan kategori sangat tinggi setelah melalui uji coba terbatas, dan dinyatakan efektif dengan kategori sangat tinggi dilihat dari hasil motivasi belajar namun belum berhasil mencapai ketuntasan kelas.

\section{B. Saran}

Berdasarkan hasil yang diperoleh dari penelitian ini, maka dikemukakan saran-saran sebagai berikut:

1. Waktu pengembangan media pembelajaran macromedia flash berbasis discovery learning diperpanjang serta mengikuti tahap model ADDIE sesuai dengan teori yang berlaku, mulai dari tahap analisis sampai evaluasi produk sehingga penelitian pengembangan dilakukan secara maksimal.

2. Media pembelajaran macromedia flash berbasis discovery learning ini perlu di evaluasi dan diuji cobakan pada skala besar untuk mendapatkan hasil yang lebih baik lagi

\section{DAFTAR PUSTAKA}

Arsyad, A. (2005). Media Pembelajaran. Jakarta: PT Raja Grafindo Persada.

Dahar, R. W. 1996. Teori-teori Belajar. Erlangga: Jakarta.

Jamil, S. (2013) Strategi Pembelajaran. Yogyakarta: Ar-Ruzz Media.

Ma'rifah. 2012. Keefektifan Pembelajaran Kimia Bersrategi Konflik Kognitif untuk Mereduksi Miskonsepsi Peserta Didik pada Pemahaman Konseptual dan Algoritmik, Skripsi. Semarang: FMIPA Universitas Negeri Semarang.

Merdekawati. (2014). Pengembangan One Stop Learning Multimedia Menggunakan Software Adobe Flash pada Materi Bentuk Molekul dan Gaya Antar Molekul Kelas XI SMA. Jurnal Pendidikan Kimia, 3(1).

Muhaimin. (2008). Pengembangan Materi Kurikulum Tingkat Satuan Pendidikan (KTSP) pada Sekolah dan Madrasah. Jakarta: PT Raja Grafindo.

Mulyatiningsih, Endang. 2011. Metode Penelitian Terapan Bidang Pendidikan. Bandung: Alfabeta.

Subhan., Pince Salempa dan Muhammad Danial. 2018. Pengaruh Media Animasi dalam 
Pengembangan Media Pembelajaran Macromedia Flash berbasis Discovery Learning pada Materi Larutan Penyangga Kelas XI MIA I SMAN 9 Makassar

Model Pembelajaran Inkuiri Terbimbing terhadap Keterampilan Berpikir Kritis dan Aktivitas Belajar Peserta Didik pada Materi Kesetimbangan Kimia. Chemistry Education Review (CER), Pend. Kimia PPs UNM Vol.1 No.2.

Sumiharsono, M.R., \& Ariyanto, H. 2017. Media Pembelajaran. Jember: Pustaka Abadi.
Tsaparlis, F. 2004. Has Educational Research Made Any Difference to Chemistry Teaching?. Chemistry Education: Research and Practice, 3-4.

Uno, H. B. 2011. Teori Motivasi dan Pengukurannya Analisis dibidang Pendidikan. Jakarta: PT Bumi Aksara. 